\title{
MODEL SPASIAL KERENTANAN DIKAWASAN PESISIR SELATAN TELUK BETUNG KOTA BANDAR LAMPUNG TERHADAP BENCANA TSUNAMI
}

\author{
Adrian \\ Dosen Program Studi Pendidikan Geografi, Universitas Islam 45 Bekasi \\ E-mail: ophunkpetrucci@gmail.com
}

\begin{abstract}
Bandar Lampung is an area in Indonesia which has a high level of Tsunami threat. It is due to the position of Bandar Lampung which is located relatively near the meeting point of Indo-Australian plate dan the Eurasian plate; both are plates are relatively active. Other causes are earthquake threat and the existence of Krakatoa which is potential to generate earthquakes which are followed by a Tsunami. The data analysis showed that the potential Tsunami hazard in the coastal city of Bandar Lampung is the predicted distance run up the marinade tsunami that reached a height of 20 meters above sea level. Potential hazards include four districts, i.e. Bumi Waras District, Panjang District, South Teluk Betung District, and East Teluk Betung District. The research method is Cell-Based modeling, the one using the tool model builder in Arc GIS with 1 meter raster grid analysis, which can show and explain in detail the attributes that exist in the region. From Quick Bird image that has of 0.6 meter resolution, the existing condition of the land use can be clearly seen.

The results of the analysis showed the vulnerability of Tsunami in the city of Bandar Lampung. The results showed that Bumi Waras District has the highest vulnerability level at Bumi Waras Subdistrict with an area of $85.62 \mathrm{Ha}$. Panjang District has the highest level of vulnerability at Pidada Subdistrict with an area of 30.16 ha. South Teluk Betung District has the highest level of vulnerability at Pesawahan Subdistrict with an area of 0,02 Ha. East Teluk Betung District has the highest level of vulnerability at Kota Karang Subdistrict with an area of $32.11 \mathrm{Ha}$.
\end{abstract}

\section{Keywords: Tsunami disaster, Vulnerability and cell-based modeling}

\section{PENDAHULUAN}

Kerentanan daerah pesisir terhadap bencana alam semakin meningkat sejalan dengan meningkatnya konsentrasi penduduk menjadikan daerah pesisir sebagai pusat-pusat aktifitas perekonomian dan kota-kota padat penduduk. Di sepanjang daerah dengan geologi aktif, salah satu bencana yang kerap terjadi adalah gempabumi yang diikuti dengan tsunami. Tsunami dapat terjadi dimana saja di daerah yang berbatasan dengan lautan lepas. Walaupun tsunami sering terjadi di daerah yang memiliki patahan paling aktif, tsunami yang banyak menelan korban jiwa terkadang terjadi di daerah yang memiliki patahan kurang aktif seperti kawasan di Lautan Atlantik dan Lautan Hindia. Tsunami Aceh tahun 2004 yang menelan korban jiwa lebih dari 200 ribu jiwa merupakan salah satu kejadian yang tidak pernah diduga sebelumnya oleh banyak pihak karena daerah ini (lepas pantai Sumatera bagian Utara hingga Myanmar) relatif jarang mengalami gempabumi yang diikuti tsunami (Sutawidjaja et al., 2006).

Penelitian kerentanan tsunami Kota Bandar Lampung dilakukan karena daerah ini mempunyai potensi besar untuk dilanda becana tsunami. Pemetaan kerentanan bencana tsunami yang dilakukan diharapkan menjadi rekomendasi untuk pengembangan daerah Kota Bandar Lampung, agar dapat mengantisipasi mengenai bencana tsunami yang kemungkinan dapat terjadi kembali di daerah ini, sehingga tidak menimbulkan kerugian dan korban yang besar.

\section{METODOLOGI PENELITIAN}

Kerentanan wilayah terhadap tsunami berdasarkan berdasarkan kondisi sosialbudaya, kondisi ekonomi, dan kondisi fisik dan lingkungan dimana dari kondisi-kondisi tersebut terdapat parameter yang mendukungnya. Parameter kerentanan wilayah terhadap banjir dalam penelitian ini yaitu: kepadatan penduduk, 
kelompok usia rentan, luas lahan produktif, tenaga kerja di sektor rentan, perumahan dan kepadatan bangunan, Infrastruktur/Fasum, fasilitas kritis, kawasan lindung, hutan bakau dan hutan alam.

Penentuan kelas kerentanan dilakukan dengan metode Cell Based Modelling, Pada studi ini pembobotan yang dipakai menggunakan nilai bobot Parameter Penyusunan Peta Kerentanan BNPB (2012) dalam analisa spasial, layer-layer berupa ratser akan menampilkan objek dalam bidang bujur sangkar, yang saling bertautan yang disebut dengan grid, setiap lokasi dalam layer rasters akan berupa grid cell-grid cell dengan ukuran 1 meter yang memiliki nilai teretentu. Selanjutnya dilakukan penyusunan basis data (baik spasial maupun non spasial) berdasarkan data yang terkumpul, lalu dibuat peta-peta tematik baik untuk parameter kerawanan dan parameter kerentanan. Keseluruhan parameter tersebut berformat raster dan kemudian dioverlay dengan menggunakan metode Weighted Overlay. Selanjutnya dilakukan proses reklasifikasi untuk menentukan tingkat kelas kerentanan tsunami.

Data yang dikumpulkan dalam penelitian ini sebagian besar berupa data sekunder dan studi kepustakaan yang bersumber dari instansi terkait. Sedangkan data primer akan didapatkan dari hasil survei kondisi lapangan

Data dalam bentuk data tabuler maupun spasial diolah dengan menggunakan software Arc GIS 10.2, Perangkat Global Mapper dan Perangkat lunak Slava ITBD.

Indeks kerentanan pesisir pantai terhadap bencana tsunami ditentukan melalui fungsi analisis dengan menggunakan metode Cell Base Modeling (CBM). Metode CBM didasarkan pada proses individu dari tiap sel yang digunakan sebagai sarana untuk menganalisis obyek di atas permukaan bumi. Setiap sel tersebut memuat parameter dan memiliki format data grid. Setiap sel yang dimaksud memiliki nilai tertentu yang besarnya tergantung dari besarnya nilai masing-masing parameter yang digunakan untuk menentukan tingkat kerawanan bencana tsunami. Hasil pemodelan tsunami dan parameter-parameter kerentanan yang sudah dijabarkan sebelumnya harus dikonversi ke dalam bentuk raster. Setiap parameter yang sudah berfomat raster direklasifikasi menjadi kelas kerawanan dan kerentanan. Pengelompokan setiap parameter tersebut mengikuti zonal fuction karena setiap parameter akan mengelompok berdasarkan kesamaan sel tersebut. Sel akan dikodekan berdasarkan kriteria yang membentuk suatu zona. Pengkodean sel (calculation) dilakukan secara otomatis oleh perangkat lunak ArcGIS sesuai dengan Parameter Penyusunan Peta Kerentanan (BNPB 2010).

Konsep ini didasarkan pada proses individu dari tiap sel (cell procesing) yang digunakan sebagai sarana untuk menganalisis objek diatas permukaan bumi, setiap sel tersebut memuat parameter yang digunakan untuk menentukan tingkat kerentanan bencana tsunami dan memiliki format data grid. Dari setiap sel yang memiliki nilai tertentu yang besarnya tergantung dari besarnya masingmasing parameter dari seluruh parameter yang digunakan, untuk menentukan tingkat kerentanan tsunami.

Menentukan kerentanan tsunami yang terlebih dahulu harus dilakukan adalah menentukan kelas kerentanan atau rentang nilai kerentanan tsunami. Tahap pertama adalah menghitung nilai kerentanan maksimum (Vmax) dan kerentanan minimum (Vmin). Nilai Vmax didapat dari mengalikan nilai bobot tertinggi dari tiap variabel dengan nilai bobot variabel tersebut, sedangkan Vmin didapat dari mengalikan nilai bobot terendah dari tiap variabel dengan nilai bobot variabel tersebut. Tujuan dari mencari nilai Vmax dan Vmin ini adalah untuk mencari selisih nilai kerentanan ( V), dengan perhitungan sebagai berikut:

\section{Nilai $\mathbf{V}=\left(\mathbf{V}_{\max }-\mathbf{V}_{\min }\right) /$ Kelas}

Nilai-nilai pada masing-masing kelas seperti yang sudah dijabarkan di atas akan dideskripsikan secara otomatis berupa klasifikasi wilayah pantai dan Pesisir Bandar Lampung berdasarkan tingkat kerentanannya terhadap bencana tsunami. Hasil model yang berhasil dibangun, baik itu model penjalaran gelombang tsunami ataupun model klasifikasi tingkat kerentanan pantai terhadap bencana tsunami untuk wilayah pantai dan Pesisir Kota Bandar Lampung dapat dibuat peta tematiknya. 


\section{HASIL DAN PEMBAHASAN}

Dalam menentukan kerentanan tsunami yang terlebih dahulu harus dilakukan adalah menentukan kelas kerentanan atau rentang nilai kerentanan tsunami. Tahap pertama adalah menghitung nilai kerentanan maksimum $\left(V_{\max }\right)$ dan kerentanan minimum $\left(\mathrm{V}_{\min }\right)$. Nilai $V_{\max }$ didapat dari mengalikan nilai bobot tertinggi dari tiap variabel dengan nilai bobot variabel tersebut, sedangkan $\mathrm{V}_{\text {min }}$ didapat dari mengalikan nilai bobot terendah dari tiap variabel dengan nilai bobot variabel tersebut. Tujuan dari mencari nilai $V_{\max }$ dan $V_{\min }$ ini adalah untuk mencari selisih nilai kerentanan ( V). Nilai $\mathrm{V}$ ini bila dibagi dengan jumlah kelas yang diinginkan maka akan didapat selang kerentanan antarkelas. Pada penelitian ini kelas kerentanan dibagi menjadi tiga yaitu: Tinggi, Sedang dan Rendah.

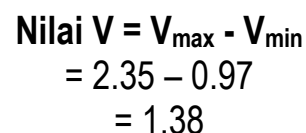

Selang kerentanan $=1.38 / 3$

$=0.46$
Peta hasil analisis dengan menggunakan Model spasial kerentanan kawasan Pesisir Kota Bandar Lampung akibat bencana tsunami dengan menggunakan metode cell based modelling dengan tool model builder dalam Arc Gis, dengan analisa grid raster 1 meter dapat menampilkan dan menjelaskan secara details atribut yang ada pada wilayah tersebut, karena peta ditampalkan dengan citra Quick Bird yang memiliki resolusi tinggi 0,6 meter sehingga dapat melihat kondisi eksisting penggunaan lahan secara jelas. Untuk mengetahui secara details atribut yang ada pada wilayah tersebut, maka peta hasil analisis ini di overlay dengan Peta Administrasi Kota Bandar Lampung.

Peta berikut ini menunjukkan tingkat kerentanan terhadap tsunami Kota Bandar lampung dapat diketahui jumlah kecamatan sekaligus kelurahan yang terdampak oleh tsunami. Setelah proses spatial data snalisis ini dilakukan maka akan dihasilkan peta tingkat kerentanan terhadap bencana tsunami. Gambar di bawah ini menunjukkan tingkat kerentanan terhadap bencana tsunami di wilayah Kota Bandar Lampung:

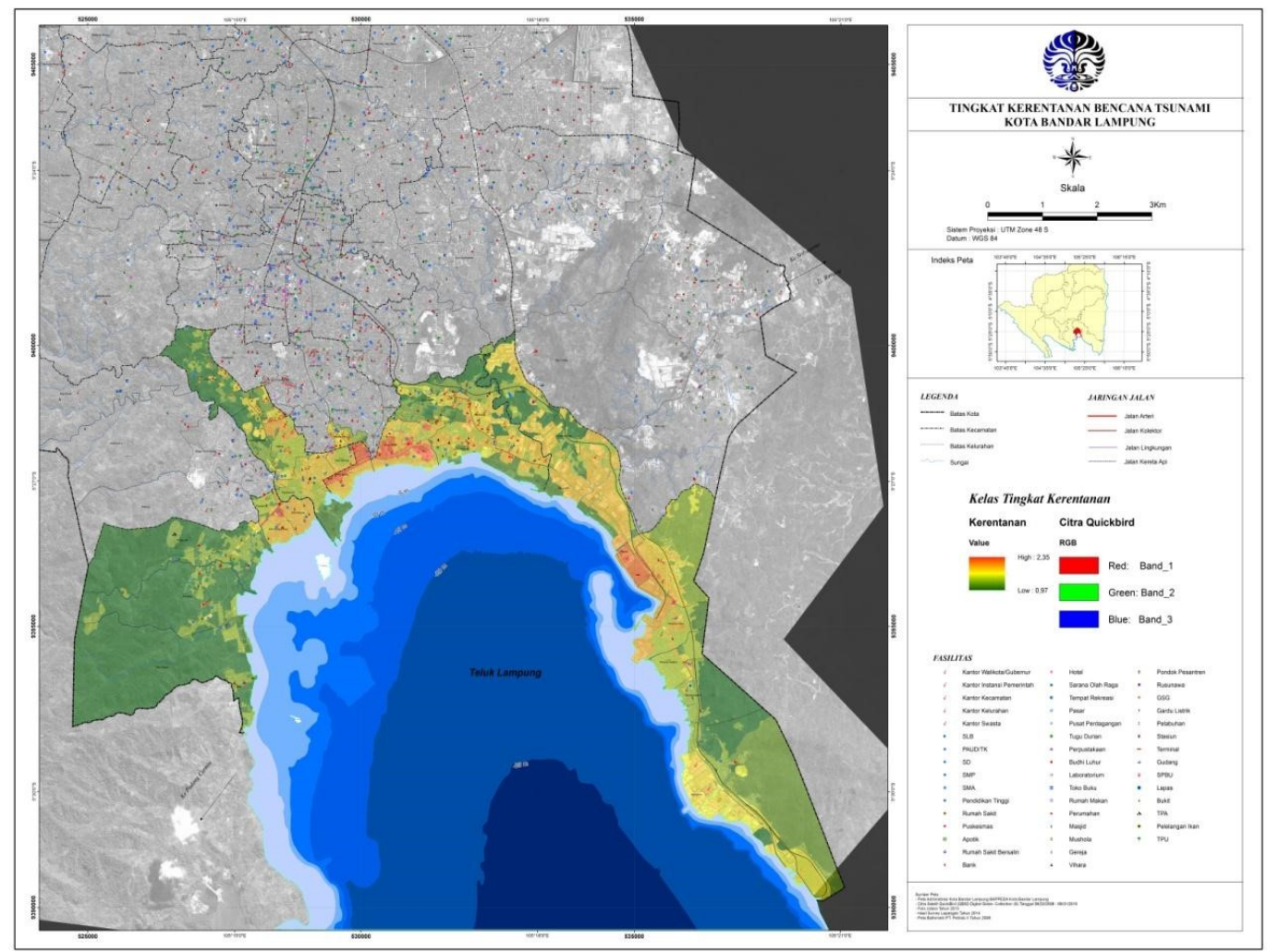

Gambar 2 Peta Tingkat Kerentanan Kota Bandar Lampung 
Peta kerentanan dapat dibagi-bagi ke dalam kerentanan sosial, ekonomi, fisik dan ekologi/lingkungan. Kerentanan dapat didefinisikan sebagai Exposure kali Sensitivity. "Aset-aset" yang terekspos termasuk kehidupan manusia (kerentanan sosial), wilayah ekonomi, struktur fisik dan wilayah ekologi/lingkungan. Tiap "aset" memiliki sensitivitas sendiri, yang bervariasi dalam intensitas bencana. Indikator yang digunakan dalam analisis kerentanan terutama adalah informasi keterpaparan. Dalam dua kasus informasi disertakan pada komposisi paparan (seperti kepadatan penduduk, dan rasio kelompok umur). Sensitivitas hanya ditutupi secara tidak langsung melalui pembagian faktor pembobotan.

Dari hasil overlay, didapatkan hasil tingkat kerentanan terhadap tsunami di Kota Bandar lampung, dalam melihat daerah yang mempunyai tingkat kerentanan yang tinggi terhadap tsunami yang digunakan adalah batas administrasi daerah, dapat diketahui sebagai berikut, Kecamatan Bumi Waras memiliki tingkat kerentanan tsunami tinggi seluas $243 \mathrm{Ha}$, tingkat kerentanan sedang seluas $111 \mathrm{Ha}$ dan tingkat kerentanan rendah seluas $86 \mathrm{Ha}$. Kecamatan Panjang memiliki tingkat kerentanan tsunami tinggi seluas $30,17 \mathrm{Ha}$, tingkat kerentanan sedang seluas $565 \mathrm{Ha}$, dan tingkat kerentanan rendah seluas $734 \mathrm{Ha}$. Kecamatan Teluk Betung Selatan memiliki tingkat kerentanan tsunami tinggi seluas 0,02 $\mathrm{Ha}$, tingkat kerentanan sedang seluas $99,46 \mathrm{Ha}$, dan tingkat kerentanan rendah seluas $269,88 \mathrm{Ha}$. Kecamatan Teluk Betung Timur memiliki tingkat kerentanan tsunami tinggi seluas $67 \mathrm{Ha}$, tingkat kerentanan sedang seluas $160 \mathrm{Ha}$, dan tingkat kerentanan rendah seluas $830 \mathrm{Ha}$.

Dalam analisa tingkat kerentanan, Kecamatan Bumi Waras memiliki tingkat kerentanan tertinggi pada Kelurahan Bumi Waras dengan luas $85,62 \mathrm{Ha}$. Kecamatan Panjang memiliki tingkat kerentanan tertinggi pada Kelurahan Pidada dengan luas 30,16 Ha. Kecamatan Teluk Betung Selatan memiliki tingkat kerentanan tertinggi pada Kelurahan Pesawahan dengan luas 0.02 Ha dan Kecamatan Teluk Betung Timur memiliki tingkat kerentanan tertinggi pada Kelurahan Kota Karang dengan luas $32,11 \mathrm{Ha}$.

Tabel 3 Tingkat Kerentanan Tsunami Kota Bandar Lampung

\begin{tabular}{|c|c|c|c|}
\hline KECAMATAN KELURAHAN & $\begin{array}{l}\text { JUMLAH } \\
\text { PENDUDUK }\end{array}$ & $\begin{array}{r}\text { TINGKAT } \\
\text { KERENTANAN }\end{array}$ & $\begin{array}{l}\text { LUAS WILAYAH } \\
\text { (Ha) }\end{array}$ \\
\hline \begin{tabular}{ll}
\multicolumn{2}{l}{ PANJANG } \\
1. & Bumi Raya \\
2. & Bumi Waras \\
3. & Garuntang \\
4. & Kangkung \\
5. & Sukaraja
\end{tabular} & 91.080 & $\begin{array}{l}\text { Tinggi } \\
\text { Sedang } \\
\text { Rendah }\end{array}$ & $\begin{array}{c}30,17 \\
565,89 \\
734,61\end{array}$ \\
\hline $\begin{array}{ll}\text { TELUKBETUNG SELATAN } \\
\text { 1. } \\
\text { 2. } \\
\text { 2. Ketang Maritim } \\
\text { 3. } \\
\text { 4. } \\
\text { 5etapang Kuala } \\
\text { 6. Panjang Selatan } \\
\text { 6. } & \text { Pidada } \\
\text { 7. } & \text { Srengsem } \\
\text { 8. } & \text { Way Lunik } \\
\end{array}$ & 50.503 & $\begin{array}{l}\text { Tinggi } \\
\text { Sedang } \\
\text { Rendah }\end{array}$ & $\begin{array}{c}0.2 \\
99,46 \\
269,88\end{array}$ \\
\hline $\begin{array}{ll}\text { TELUKBETUNG TIMUR } \\
\text { 1. } & \text { Gedong Pakuan } \\
\text { 2. } & \text { Gunung Mas } \\
\text { 3. } & \text { Pesawahan } \\
\text { 4. } & \text { Sumur Putri } \\
\text { 5. } & \text { Talang } \\
\text { 6. } & \text { Teluk Betung }\end{array}$ & 52.039 & $\begin{array}{l}\text { Tinggi } \\
\text { Sedang } \\
\text { Rendah }\end{array}$ & $\begin{array}{c}67,41 \\
160,97 \\
830,13\end{array}$ \\
\hline $\begin{array}{ll}\text { BUMI WARAS } \\
\text { 1. } & \text { Keteguhan } \\
\text { 2. } & \text { Kota Karang } \\
\text { 3. } & \text { Kota Karang Raya } \\
\text { 4. } & \text { Perwata } \\
\text { 5. } & \text { Sukamaju } \\
\text { 6. } & \text { Way Tataan }\end{array}$ & 68.762 & $\begin{array}{l}\text { Tinggi } \\
\text { Sedang } \\
\text { Rendah }\end{array}$ & $\begin{array}{c}243,02 \\
111,2 \\
86,45\end{array}$ \\
\hline
\end{tabular}


Berdasarkan hasil analisis terhadap variabel kerentanan dan bahaya tsunami Kota Bandar Lampung, maka ada 2 (dua) Kecamatan yang disarankan diprioritaskan dalam mitigasi bencana tsunami di Kota Bandar Lampung, karena terletak pada daerah kerentanan tinggi bencana tsunami, yaitu: Kecamatan Bumi Waras dan Kecamatan Panjang sedangkan untuk dua Kecamatan yaitu: Kecamatan Teluk Betung Selatan dan Kecamatan Teluk Betung Timur memiliki tingkat kerentanan sedang bencana tsunami, kedua Kecamatan tersebut merupakan daerah industri dan adanya fasilitias vital, yaitu pergudangan, pelabuhan dan pembangkit listrik, dan kedua daerah tersebut merupakan pusat perekonomian Kota Bandar Lampung.

\section{KESIMPULAN}

Kota Bandar Lampung dari analisis data ditemukan bahwa potensi bahaya bencana tsunami di pesisir Kota Bandar Lampung diperoleh prediksi jarak run up rendaman tsunami mencapai ketinggian 20 meter, yang mencakup 4 kecamatan yaitu (Kecamatan Bumi Waras, Kecamatan Panjang, Kecamatan Teluk Betung Selatan dan Kecamatan Teluk Betung Timur). Tingkat Kerentanan Tsunami tertinggi Kota Bandar Lampung seluas $243 \mathrm{Ha}$ terletak di Kecamatan Bumi Waras, 67,41 Ha terletak di Kecamatan Teluk Betung Timur, 0,2 Ha terletak di Kecamatan Teluk Betung Selatan dan $67,41 \mathrm{Ha}$ terletak di Kecamatan Panjang. Tingkat Kerentanan Tsunami sedang Kota Bandar Lampung seluas 111,2 Ha terletak di Kecamatan Bumi Waras, 160,97 Ha terletak di Kecamatan Teluk Betung Timur, 99,46 Ha terletak di Kecamatan Teluk Betung Selatan dan 565,89 Ha terletak di Kecamatan Panjang. Tingkat Kerentanan Tsunami rendah Kota Bandar Lampung seluas 86,45 Ha terletak di Kecamatan Bumi Waras, 830,13 Ha terletak di Kecamatan Teluk Betung Timur, 269,88 Ha terletak di Kecamatan Teluk Betung Selatan dan 734,61 Ha terletak di Kecamatan Panjang.

Model spasial kerentanan kawasan pesisir Kota Bandar Lampung akibat bencana tsunami dengan menggunakan metode cell based modelling dengan tool model builder dalam Arc Gis, dengan analisa grid raster 1 meter mampu menampilkan tingkat kerentanan yang cukup akurat dari 4 variabel yang digunakan, yaitu sosial kependudukan, sosial ekonomi, fisik dan lingkungan, dengan tampalan citra pankromatik Quickbird dengan rosulusi 0,6 meter mampu melihat kondisi eksisting penggunaan lahan secara jelas.

\section{DAFTAR PUSTAKA}

Badan Nasional Penanggulangan Bencana (BNPB), (2010). Rencana Nasional Penanggulangan Bencana Nasional 20102014. Jakarta.

Badan Nasional Penanggulangan Bencana (BNPB), (2012). Masterplan Pengurangan Risiko Bencana Tsunami. Jakarta.

Diposaptono, S. (2006). Mitigasi Bencana Wilayah Pesisir Berbasis Ekosistem Mangrove. Ditjen Kelautan, Pesisir, dan Pulau-pulau Kecil DKP. Jakarta.

ESRI (Environmental System Research Institute). (2004). Using ArcGis Spatial Analyst. ESRI Institute, Inc. New York. USA.

Harada, K dan Imamura, F. (2003). Study on The Evaluation of Tsunami Reducing by Coastal Control Forest for Actual Conditions. Asia and Pasific Coast. Japan

Latief. (2005). Prakiraan Pembangkitan Tsunami Menyusul Kejadian Gempa (Studi Kasus Tsunami Flores 1992) in Penerapan Hasil Riset Untuk Penanggulangan Bencana Tsunami di Indonesia (Sadikin et al. eds). BPPT Press. Jakarta. Pp. 27-52.

National Tsunami Hazard Mitigation Program.( 2001). Menghadapi Tsunami: Tujuh Prinsip Perencanaan dan Perancangan. Washington

Naryanto, H.S., (2003). Mitigasi Kawasan PantaiSelatan Kota Bandar Lampung, PropinsiLampung Terhadap Bencana Tsunami. Jurnal ALAMI, Vol. 8, No. 2 Th. 2003

Naryanto, H.S., (2006). Kajian Potensi dan Zonasi Kerentanan Bencana Tsunami di Bandar Lampung-Kalianda, Provinsi Lampung. Jurnal ALAMI, Vol. 11, No. 2 Th. 2006 
Peraturan Menteri Dalam Negeri no. 33 Tahun (2006) Tentang Pedoman Umum Mitigasi Bencana

Purwadhi F. Sri Hardiyanti (2008). Pengantar Interpretasi Citra Penginderaan Jauh, LAPAN, Indonesia

Semeidi Husrin, Dkk (2012). Kerentanan Infrastruktur Strategis Terhadap Bencana Tsunami Di Sumatera Barat, Badan Penelitian dan Pengembangan Kelautan dan Perikanan. Padang

USGS, (2014). (United State Geologyc Survey). Data http://neic.usgs.gov/neic/epic/epic_rect.ht $\mathrm{ml}$

White, J.D.L., (2007). Ocean Drilling and Hazards of Submarine Volcanic Eruptions, dipresentasikan pada pertemuan Geohazard-IODP 26-30 Agustus 2007, Portland - Oregon, Amerika Serikat.

Yussahnonta, Panca. (2006). Identifikasi Daerah Bahaya Tsunami dan Strategi Mengurangi Resikonya di Kota Padang. ITB. Bandung. 